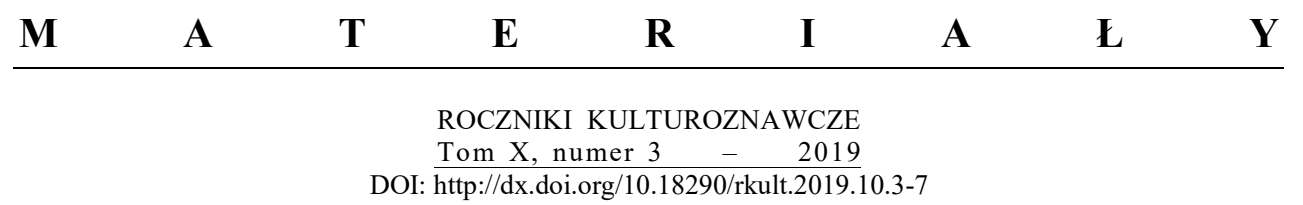

ROBERT BOROCH

\title{
SALVATION FROM OBLIVION: TEOFILA BOBKO-JANKOWSKA (1920-2009)*
}

\section{INTRODUCTION}

The concept of regional literature became a permanent part of literary studies at the turn of the twentieth and twenty-first centuries, despite its definitional vagueness, which resulted from the logical and analytical difficulty of combining the scopes of the terms literariness and regionality. These specialist terms ${ }^{1}$ from academic subdisciplines-literariness is a specialist term in literary theory, ${ }^{2}$ regionality in ethnography and social anthropology ${ }^{3}$-are categories distinguishing literature as a work of art in two areas. The first is the aesthetic area, referring to those values which make a subject, such as a literary work, an aesthetic subject — a work of literary art. The second term refers

Dr RoBERT BOROCH - Department of Central and East European Intercultural Studies, Faculty for Applied Linguistics, University of Warsaw, correspondence address: ul. Szturmowa 4, 02-678 Warszawa, e-mail: robboroch@outlook.com; ORCID: https://orcid.org/0000-0002-2016-5449.

* I would like to thank Ms Alicja Kosewska-Terech for providing access to archival materials and for the inspiration to undertake research documenting the work of Ms Teofila Bobko-Jankowska.

${ }^{1}$ See Jerzy LukszYn \& Wanda ZMARZER, Teoretyczne podstawy terminologii [Theoretical foundations of terminology] (Warsaw: Department of Specialist Languages UW, 2001).

${ }^{2}$ Literariness is a term of literary theory introduced to the study of literary art in 1921 by Roman Jakobson in a paper entitled Novejšaja russkaja poezija [Slovenian: Recent Russian poetry] (1921). This researcher defined as literariness those qualities of a literary work that give it aesthetic status - that of a work of literary art. See Roman JAKOBSON, "Poetyka w świetle językoznawstwa" [Poetics in the light of linguistics], trans. Krystyna Pomorska, Pamiętnik Literacki [Literary diary] no. 2(1960): 431-473.

${ }^{3}$ Regionality is a colloquial term that means only 'being associated with or characteristic of a given region' or 'being known, used, or appearing in a specific region, coming from a given region.' See Uniwersalny Stownik Języka Polskiego [Universal Dictionary of the Polish Language], electronic version 2.0. (Warsaw: Wydawnictwo Naukowe PWN, 2008). 
to the theme of a work of literary art which is related to a specific geographical region, culture, or history, or to the traditions of a social group or groups that inhabit that region. Aesthetic categories, in the case of regional literature, are secondary. What comes to the fore here is the strength of the social influence not of the work of literary art but of its creator, who is linked with the environment in which he or she functions on a daily basis. In this sense, too, the strength of the social influence of the creator and of his or her work takes on an anthropological dimension, which defines the purpose of the present article: the documentation of the work of the local poet, pedagogue, and teacher, Teofila Bobko-Jankowska (1920-2009). The material presented here is of a documentary character, thus the issues raised fall directly into the category of the preservation of Polish cultural values.

\section{WARMIA: ETHNOGRAPHIC INFORMATION}

Warmia covers an area of $4,250 \mathrm{~km}^{2}$, constituting $17.6 \%$ of the area of the Warmian-Masurian Voivodeship. Historic Warmia includes cities such as Olsztyn, Braniewo, Lidzbark Warmiński, Biskupiec, Dobre Miasto, Orneta, Barczewo, Reszel, Jeziorany, Pieniężno, Bisztynek, and Frombork. After 1945, the entire geographical area of Warmia was incorporated into Poland. Historically, Warmia was surrounded on the north by Lower Prussia and Sambia, on the south-west by Upper Prussia and the Powiśle area, and on the south-east by Masuria. The border between Poland and the Russian Federation in this region is $209.73 \mathrm{~km}$ long, ranging throughout Warmia. Currently (2019), the inhabitants of Warmia are largely individuals who were displaced from the borderlands or Mazovia, or by Operation Vistula. ${ }^{4}$ The following national minorities are active in Warmia (in order of their size): Ukrainian, German, Belarusian, Russian, Jewish, Lemko, Romani, Armenian, Lithuanian.

\section{BISKUPIEC: ETHNOGRAPHIC INFORMATION, CULTURAL LIFE OF THE CITY}

Biskupiec (German: Bischofsburg Ostpreußen) is a city located in the Warmian-Masurian Voivodeship, in the Olsztyn powiat, about 39 kilometres from

\footnotetext{
4 'Operation Vistula': the name given to the deportation of the Ukrainian population to the western and northern territories of Poland in 1947-50. See http://www.zup.ukraina.com.pl/index.php?option =com_content\&task=view\&id=80 (accessed: 20.01 .2019 ).
} 
the city of Olsztyn (German: Allenstein) in the direction of Mrągowo (German: Sensburg). The city was formally located within the borders of Poland following the end of World War II. Biskupiec possesses a rich Polish-German history. ${ }^{5}$ Its cultural (and literary) life in the years 1960-2009 has not been well documented. Most archival materials are found in school libraries, Halls of Memory within schools, the City Library, or private hands. Materials documenting the history and cultural life of the city are collected by hobbyists and regional enthusiasts. ${ }^{6}$ One rich source of information about the cultural and historical heritage of the city can be found in academic theses prepared at the nearby University of Warmia and Mazury in Olsztyn. ${ }^{7}$ A huge role in the development of the city's cultural life has also been played by language and history teachers as well as librarians of the City and Pedagogical Libraries, which have succeeded in accumulating a rich collection of historic factographic material. ${ }^{8}$

\section{TEOFILA BOBKO-JANKOWSKA (1920-2009)}

\subsection{BIOGRAPHICAL INFORMATION ${ }^{9}$}

Teofila Bobko-Jankowska was born on 24 June 1920, in Krasienice near Przemyśl, to a Polish-Russian family. In 1926, she moved with her parents to

\footnotetext{
${ }^{5}$ Robert TEICHERT, Geschichte der Stadt Bischofsburg [History of the city of Bischofsburg] (Bischofsburg: Franz Harich, 1936).

${ }^{6}$ Notable promoters of culture and regional researchers, e.g. Alicja Kosewska-Terech, Krzysztof Kowalski, Joanna Kowalczyk. Source: http://leksykonkultury.ceik.eu/index.php/Strona_g\% C5\%82\%C3\%B3wna (accessed: 20.01.2019).

${ }^{7}$ Source: (1) Joanna KowalczyK, Dzieje Szkoły Podstawowej nr 3 im. Orła Białego w Biskupcu $w$ latach 1963-2005 [History of the White Eagle Primary School No. 3 in Biskupiec, 1963-2005] [manuscript, academic thesis, Olsztyn 2006]; (2) memoirs of Janusz Leśniewski from the years 194552: http://www.loszczytno.edu.pl/absolwenci/wspomnienia/lesniewski.pdf (accessed: 20.01.2019). Source (1) was developed based on the following material: (a) Informational Bulletin of the Municipal Office in Biskupiec (no date); b) Gazeta Olsztyńska [Olsztyn Gazette] with the addition Nasza Warmia [Our Warmia] (no date-RB); (c) Gazeta Szkolna [Scholastic Gazette] (no bibliographical information-RB); (d) Statute of Primary School no. 3 in Biskupiec; (e) website www.sp3biskupiec. webpark.pl (inactive page; material in my possession-RB); (f) archival sources of the school (inventory of the archive not listed-RB).

${ }^{8}$ Also school libraries in primary schools nos. 1,2, and 3, and the middle schools.

${ }^{9}$ Information collected on the basis of: (1) an interview given by Bobko-Jankowska in 2003, which was published on the website http://biskupiec.com.pl/biskupczanie/259/przeprowadzki-paniteofilii-jankowskiej (accessed: 20.01.2019) (2) an obituary placed by the family in Gazeta Olsztyńska [Olsztyn Gazette] on 19 November 2009.
} 
France, where she was educated at a local six-year primary school. Upon finishing school at the age of 13 , she began to work at a nearby textile factory without interrupting her studies, which she continued on a part-time basis in middle school until age 21. At the beginning of the 1940s, she spent two months in Algeria with her younger sister, who lived there with her husband. During the occupation, she was active in the French Resistance movement, for which she was awarded the French equivalent of the Polish Medal of Victory and Freedom: the Croix de Lorraine. In the 1950s, she was displaced from France along with her family. Initially, she lived in Szklarska Poręba, then moved to Ruciane-Nida, ultimately settling in Biskupiec (German: Bischofsburg Ostpreußen) where she took a position as a foreign language teacher in a local middle school, teaching English, French, and Latin. She died 9 November 2009, and was buried in the Military Cemetery in Powązki in Warsaw, section A43, row 1, grave 6. Teofila Bobko-Jankowska was a member of the following societies and associations: the Society of French Poets, the 'Rhine and Danube' Veterans' Association, and the Association of War Invalids of the Polish Republic (Olsztyn branch). Her decorations include the Knight's Cross of the Order of Polonia Restituta, the Gold Cross of Merit, the Partisan Cross, and an Honorary Badge of 'Service to Warmia and Masuria'. She was the author of two self-published volumes of poetry entitled Syncopes-synkopy [Syncopations] (2002) and Po co? [What for?] (2003).

\subsection{POETRY: BIBLIOGRAPHIC DESCRIPTION}

\subsubsection{SYNCOPATIONS ${ }^{10}(2002)$}

A volume of poetry published by the author in 2002 at a small printing company in Biskupiec; the computer layout was done by the small printing company and the Polish-French centre in Olsztyn. Illustrated by Lilia Ciemerych, the volume, which bears the ISBN publication number 83911934-0-3, contains 88 pages, consisting of 21 poems written in French and translated into Polish by the poet herself. Placed at the end of the volume is an afterword in French by Jacques-François Dussettier, president of the Association of French Poets, along with a translation by Nicole Korzycka, the

\footnotetext{
${ }^{10}$ Syncope [French: syncopation]: the shift of a natural metric accent to an unaccented sound by means of prolongation of the rhythmic value of an unaccented note. Uniwersalny stownik języka polskiego [Universal dictionary of the Polish language] 2008.
} 
poet's sister. ${ }^{11}$ The volume can be found in the collections of the Municipal Library in Biskupiec (catalogue no. 81756) as well as those of the National Library in Warsaw (catalogue no. 2.203.082 A); the edition is out of print.

\subsubsection{WHAT FOR? (2003)}

A volume of poetry published by the author in 2002 at a small printing company in Biskupiec; the ISBN publication number is 83-9119334-1-1; the volume contains 45 pages. The volume consists of 39 poems written in Polish. ${ }^{12}$ The volume can be found in the collections of the Municipal Library in Biskupiec, catalogue no. 81754.

\subsubsection{OTHER PUBLICATIONS}

T. Bobko-Jankowska also published in a local magazine, Pod Tytutem [Under the title], in issue 2, year 2008, page 12- 'The Wind', ${ }^{13}$ 'Let me go...,,${ }^{14}$ and 'Life (?)' ${ }^{15}$ — as well as in issue 3, year 2008, page $11 .^{16}$

\subsubsection{SUMMARY}

Teofila Bobko-Jankowska, as a poet, pedagogue, and teacher of foreign languages (French, English, and Latin), made a permanent mark for herself in the cultural history of Biskupiec, promoting, among young people, a love for the French and English languages and literature.

${ }^{11}$ The volume includes: (1) 'A word from the author'; (2) 'Poetry is'; (3) 'Each of us'; (4) 'Requiem'; (5) ‘My God!'; (6) 'Unrequited love'; (7) 'The wind's caress'; (8) 'Baltic'; (9) 'The wind'; (10) 'The threat of the titan'; (11) 'Roses, my roses'; (12) 'Let me go'; (13) 'A certain nostalgia'; (14) 'Postcard'; (15) ‘Roads'; (16) ‘Testament'; (17) ‘Already'; (18) ‘Destiny’; (19) ‘Tears'; (20) 'Litany'; (21) 'Dust'.

12 The volume includes: (1) 'What for'; (2) 'To be here, there, and ... nowhere'; (3) 'You and ...'; (4) 'July in Busko'; (5) 'Silence'; (6) 'Rags'; (7) 'Ah, this memory'; (8) 'I'm a bit alienated'; (9) 'The prose of life'; (10) 'It keeps coming back to them'; (11) 'Elegy'; (12) 'On the trail of 1939-45'; (13) 'Conversation'; (14) 'Consolation'; (15) 'Writing, talking ... '; (16) 'One must choose'; (17) 'I'm seized by a strange mania'; (18) 'That's not it'; (19) 'Life(?)'; (20) 'How?'; (21) 'The void'; (22) 'The house'; (23) 'The grandchildren's questions'; (24) 'Impression'; (25) 'Stars'; (26) 'What happened to you'; (27) 'Poetry!'; (28) 'To look your friends in the eye'; (29) 'A word on the wind'; (30) 'Ocean!'; (31) 'Life itself'; (32) 'Or dreams'; (33) 'Returns'; (34) 'Seasons'; (35) 'The delicate one flew here'; (36) 'Helicopter'; (37) 'Do we know?'; (38) 'Spring!'; (39) 'Time!'.

${ }^{13}$ Teofila Bobko-Jankowska, “The wind,” Pod Tytutem no. 2(2008): 12.

${ }^{14}$ EADEM, "Let me go...," Pod Tytutem no. 2(2008): 12.

${ }^{15}$ EADEM, "Life (?)," Pod Tytutem no. 2(2008): 12.

${ }^{16}$ EAdEM, "The prose of life," Pod Tytutem no. 3(2008): 11. 


\section{CONCLUSION}

The present article provides a documentary sketch of the local poet Teofila Bobko-Jankowska. This kind of documentation is particularly essential in the context of regional and anthropological research on Polish literature. The latter area is especially important because it enables regional literature to be examined not in terms of aesthetic criteria, which are universally applicable, but in its social aspect, as one of the manifestations of the cultural life of small social structures. Warmia, after 1945, constitutes a special area for research because of the historical-political and social complexity which led to the phenomenon of 'living cultural overlap' of various national groups. The foundation of this phenomenon was the native culture (host culture), that of East Prussia. The cultural synergy of Warmia is phenomenal and in many respects interesting, especially in terms of cultural anthropology and intercultural communication. It can be observed that local creators of culture contribute to the expansion of the capacity for the production of local culture, which translates directly into an expansion of production potential. Capacity is understood here as actual cultural goods, currently produced, tangible and intangible, whereas production potential is understood as production reserves. Production capacity is fixed in institutional terms, e.g. through the operation of museums, theatres, libraries, schools, etc., whereas production potential is a matter of the inventiveness and creativity of individuals - cultural leaders of small social structures with significant social impact, e.g. teachers, writers, cultural promoters, priests, etc. The relationship between productive capacity and productive potential is actually characterised by interbreeding, which creates particular conditions for intercultural communication. Teofila Bobko-Jankowska, as a local cultural leader, undoubtedly contributed to the growth of the productive potential of the local community through the popularisation of English and French as foreign languages, and of French and Polish literature.

\section{BIBLIOGRAPHY}

Bobko-Jankowska, Teofila. What for? Biskupiec: Zakład Małej Poligrafii, 2003.

Bobko-Jankowska, Teofila. "Let me go.” Pod Tytułem no. 2(2008): 12.

Bobko-Jankowska, Teofila. "The prose of life." Pod Tytułem no. 3(2008): 11.

Bobko-JAnkowska, Teofila. Syncopes - synkopy [Syncopations]. Translated Teofila Bobko-Jankowska. Biskupiec: Zakład Małej Poligrafii, 2002.

Bobko-JAnKowska, Teofila. "The wind.” Pod Tytułem no. 2(2008): 12. 
BoBko-JANKowsKa, Teofila. "Life (?).” Pod Tytułem no. 2(2008): 12.

KowAlCZYK, Joanna. Dzieje Szkoty Podstawowej nr 3 im. Orla Biatego w Biskupcu w latach 19632005 [History of the White Eagle Primary School No. 3 in Biskupiec, 1963-2005], (manuscript).

LuKSZYN, Jerzy \& Wanda ZMARZER. Teoretyczne podstawy terminologii [Theoretical foundations of terminology]. Warsaw: Department of Specialised Languages UW, 2001.

Przeprowadzki Pani Teofilii Jankowskiej [The relocations of Ms Teofila Jankowska]. http://biskupiec. com.pl/biskupczanie/259/przeprowadzki-pani-teofilii-jankowskiej (accessed: 3.02.2020).

TEICHERT, Robert. Geschichte der Stadt Bischofsburg [History of the city of Bischofsburg]. Bischofsburg: Franz Harich, 1936.

\section{OCALIĆ OD ZAPOMNIENIA: TEOFILA BOBKO-JANKOWSKA (1920-2009)}

\section{Streszczenie}

Artykuł stanowi dokumentację twórczości miejscowej poetki Teofili Bobko-Jankowskiej (19202009) związanej z warmińską miejscowością Biskupiec. Zebrany materiał należy do kategorii badań nad regionalizmem i antropologią literatury polskiej, stanowiąc dokumentację wytworów kultury powstałych w małych strukturach społecznych oraz siły ich społecznego oddziaływania na procesy związane z ochroną kultury w regionie warmińskim po roku 1945. W tym kontekście literatura regionalna i lokalni twórcy kultury wywierają wpływ na możliwości wytwórcze miejscowej kultury, co przekłada się bezpośrednio na rozwój i konsolidację potencjału twórczego kultury miejscowej.

Słowa kluczowe: regionalność; literatura regionalna; antropologia literatury.

\section{SALVATION FROM OBLIVION: TEOFILA BOBKO-JANKOWSKA (1920-2009)}

\section{Summary}

The article documents the work of the local poet Teofila Bobko-Jankowska (1920-2009), who is associated with the Warmian town of Biskupiec. The collected material on the subject falls within the category of studies on regionalism and on the anthropology of Polish literature, documenting the cultural products of small social structures as well as the strength of their social influence on the processes of the preservation of culture in the Warmia region after 1945. In this context, regional literature and local creators of culture influence the expansion of the productive capacities of the local culture, which translates directly into expansion and consolidation of the local culture's productive potential.

Key words: regionality; regional literature; anthropology of literature. 